http://dx.doi.org/10.11646/zoosymposia.13.1.7

http://zoobank.org/urn:lsid:zoobank.org:pub:16D27C71-5A6C-4ADF-AD6C-6B07C2773112

\title{
The Family Seguenziidae Verrill, 1884 in the Northeast Pacific, including a comment on excessive numbers of taxonomic data portals
}

\author{
DANIEL L. GEIGER
}

Santa Barbara Museum of Natural History, 2559 Puesta del Sol, Santa Barbara, CA 93105, USA. E-mail: dgeiger@sbnature2.org

\begin{abstract}
The family Seguenziidae, including the genus Adeuomphalus, of the northeast Pacific are here revised. Seguenzia megaloconcha Rokop, 1972 is here synonymized under S. cervola Dall, 1919, S. quinni McLean, 1985 is here synonymized under S. gioviae Dall, 1919, S. catalina Dall, 1919 and S. certoma Dall, 1919 are synonymized under $S$. stephanica Dall, 1908. They represent either growth stages of one another, or are based on insignificant minor sculptural differences. A short commentary on the contraproductive proliferation of taxonomic data portals and the need for a single resource akin to GenBank is given.
\end{abstract}

\section{Introduction}

This contribution was started by the late James H. McLean as part of his Northeast Pacific Gastropod book project. The manuscript in outline form was significantly modified and few of McLean's taxonomic indications in the manuscript were accepted. Dimensions given are for maximum size in any axis. Abundance indications have been omitted because the number of samples from bathyal and abyssal depths is very small, which precludes any meaningful assessment of their true abundance.

Seguenziidae is a relatively small family with some 168 valid species listed in World Register of Marine Species (WoRMS) or MolluscaBase, which are identical for marine taxa (Bouchet 2018). It is generally a deep-water group, with relatively little material available. The most significant contributions have been those of Marshall (1983, 1991), Quinn (1983a, 1983b, 1987, 1991), and Poppe et al. (2006). The northeast Pacific fauna has had sporadic contributions by Dall (1908, 1919), Rokop (1972), Quinn (1983a, 1983b), McLean (1985), and Geiger (2017).

While the group once was considered a deep divergence within archaeogastropods in the subclass Seguenziina (Salvini-Plawen \& Haszpurnar 1987), it is now recognized as a specialized off-shoot within the larger Trochoidea (Kano 2008, Geiger 2012). The latest classification in Bouchet (2018) continues with the proliferation of higher taxa in Vetigastropoda and places Seguenziidae in its own order Seguenziida, which regrettably obfuscates [one of McLean's favorite terms] the sister-group relationships with trochoidean lineages. As discussed elsewhere (Geiger 2012), the relationships of vetigastropod lineages remains far from settled. Many key lineages have never been included in any phylogeny (e.g., Pendromidae, Larocheidae) and each study, each using a particular array of taxa, produces radically different sistergroup relationships; see Geiger (2012) for detailed discussion. Accordingly, it would be better to abstain from rearranging vetigastropod higher taxa until multiple phylogenies with different markers and somewhat different taxa recover highly similar relationships. For this reason, I elect to ignore the ordinal taxa given in Bouchet (2018) as he erroneously suggests that we know the evolutionary history of larger vetigastropod lineages with any degree of certainty. 


\section{Abbreviations}

LACM: Natural History Museum of Los Angeles County, Malacology Department, California, USA.

MNHN: $\quad$ Muséum National d'Histoire Naturelle, Paris, France.

ZIN: $\quad$ Zoological Institute of the Russian Academy of Sciences, St. Petersburg, Russia.

USNM: United States National Museum of Natural History, Smithsonian Institution, Washington (DC), USA.

OD: $\quad$ Original designation.

SD: $\quad$ Subsequent designation.

M: $\quad$ Monotypy.

\section{Systematics}

\section{Seguenziidae Verrill, 1884}

(Figures 1-3)

Description. Shell trochiform, turbiniform, or planispiral, 2-10 $\mathrm{mm}$, umbilicus narrow or anomphalous, interior nacreous except Adeuomphalus. Peritreme incomplete (entire in Adeuomphalus), aperture lacking a slit or foramen, but some genera with up to three labral sinuses. Operculum corneous, paucispiral.

Remarks. In the northeast Pacific, all sequenziid species occur on outer continental shelves at deep to abyssal depths, where they are detritivores (Quinn, 1983b). Specimens are seldom collected and the family is poorly known.

\section{Carenzia Quinn, 1983}

(Figure $1 \mathrm{~A}-\mathrm{C}$ )

Carenzia Quinn, 1983a: 355. Type species (OD): Seguenzia carinata Jeffreys, 1876. Amphi-Atlantic.

Description. Shell conical, smooth, whorl carinate, mid-whorl carination more or less distinct; base convex, umbilicus narrow; apertural sinuses at periphery, base indistinct.

\section{Carenzia golikovi Geiger, 2017}

(Figure 1A-B)

Carenzia golikovi Geiger, 2017: 228-229, figs 1-18. Holotype LACM 3317. 5180 m, abyssal plain W of Oregon, S of Gulf of Alaska, Alaska $\left(45^{\circ} 00^{\prime} \mathrm{N}, 153^{\circ} 47.7^{\prime} \mathrm{W}\right.$ to $\left.45^{\circ} 02.3^{\prime} \mathrm{N}, 153^{\circ} 55.9^{\prime} \mathrm{W}\right)$.

Description. Shell to $5 \mathrm{~mm}$, trochiform, whorls rounded, carination on mid shoulder; base convex, more than one dozen irregularly spaced, spiral lines of variable strength; umbilicus narrow, with indistinct funiculus; axial growth lines indistinct.

Distribution. Aleutian Trench $\left(52^{\circ} \mathrm{N}, 176^{\circ} \mathrm{W}\right)$ to S Gulf of Alaska, Alaska $\left(45^{\circ} \mathrm{N}, 154^{\circ} \mathrm{W}\right) .5100 \mathrm{~m}$.

\section{Carenzia inermis Quinn, 1983}

(Figure 1C)

Carenzia inermis Quinn, 1983a: 362, figs 13-16. Holotype LACM 1806. Cascadia Abyssal Plain, Oregon, 2820 m.

Description. Shell to $7 \mathrm{~mm}$, white, whorls inflated, suture impressed; base convex, basal angulation indistinct; umbilicus narrow, with funiculus arising from columellar wall. Mid-whorl carination of early whorls faint; later whorls nearly smooth, with weak spiral threads; growth lines showing V-shaped sinus below suture and less prominent basal sinus.

Distribution. Off Oregon $\left(44.5^{\circ} \mathrm{N}, 125.5-128^{\circ} \mathrm{W}\right) .2800 \mathrm{~m}$. 


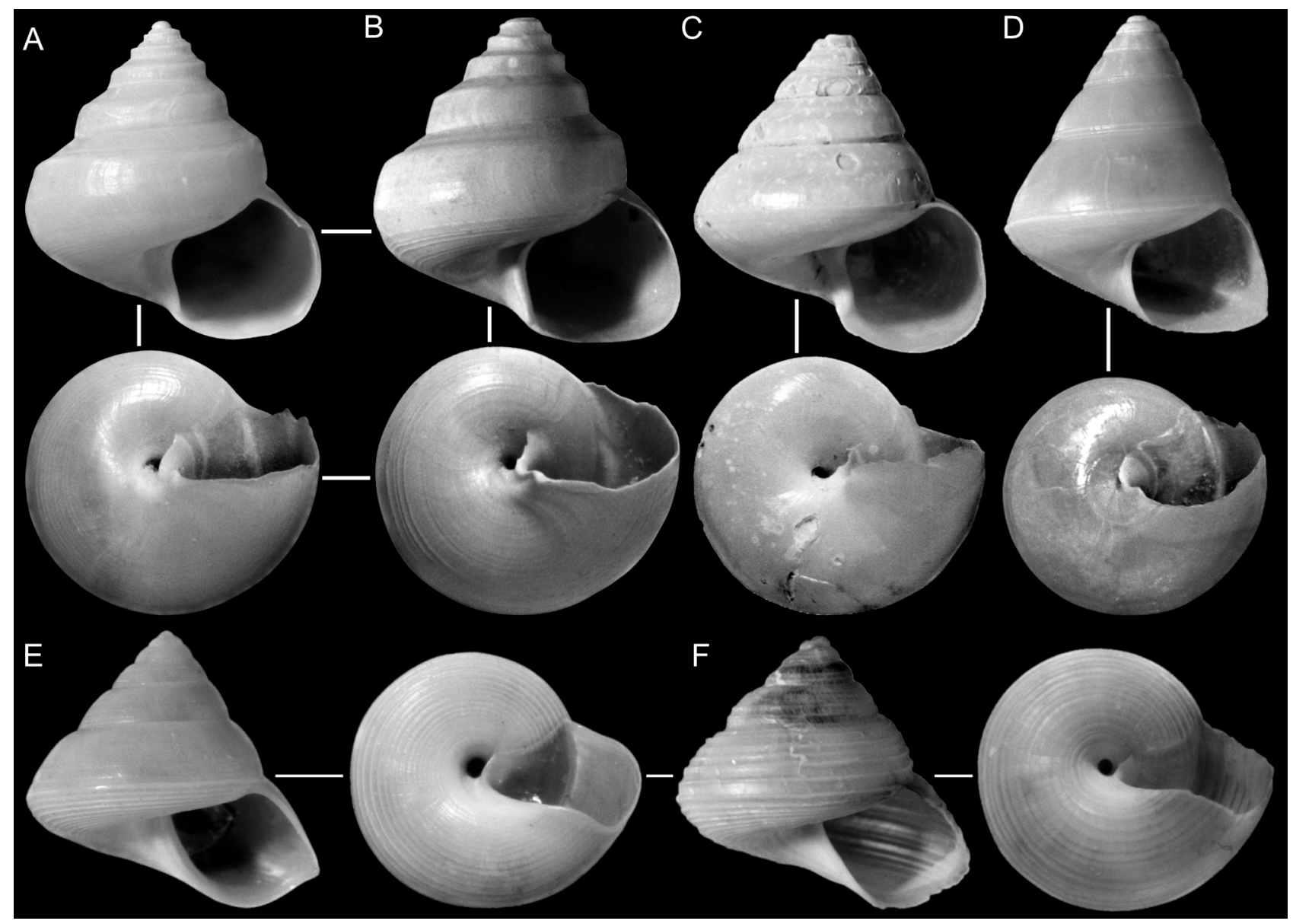

FIGURE 1. A-B. Carenzia golikovi Geiger, 2017. A. 5180 m, Abyssal plain W of Oregon, S of Gulf of Alaska, Alaska (approximately $45^{\circ} \mathrm{N}, 153.8^{\circ} \mathrm{W}$ ) (LACM 3317, holotype), $5.3 \mathrm{~mm}$. B. $5100 \mathrm{~m}$, Aleutian Trench, Alaska [near western end of chain], (52 $\left.12^{\prime} \mathrm{N}, 175^{\circ} 44^{\prime} \mathrm{E}\right)$ (LACM 3318, paratype). C. Carenzia inermis Quinn, 1983. $2820 \mathrm{~m}$, Cascadia Abyssal Plain, off Oregon (LACM 1806, holotype), $6.8 \mathrm{~mm}$. D. Asthelys careyi Geiger, 2017. $5180 \mathrm{~m}$, abyssal plain W of Oregon, S of Gulf of Alaska, Alaska (approximately 45 $\mathrm{N}, 153.8^{\prime} \mathrm{W}$ ) (LACM 3320, holotype), $7.0 \mathrm{~mm}$. E-F. Oligomeria conoidea Galkin \& Golikov, 1985. E. 166 m, S of Attu Island, Aleutian Islands, Alaska (LACM 1997-163.7), 5.9 mm. F. 219 m, NE of Semisopochnoi Island, Aleutian Islands, Alaska (LACM Station 86-330), $4.7 \mathrm{~mm}$.

\section{Asthelys Quinn, 1987}

(Figure 1D)

Asthelys Quinn, 1987: 66. Type species (OD) Basilissa munda Watson, 1879. Atlantic Ocean.

Description: Shell small, biconical, bicarinate whorls macroscopically smooth, aperture trapezoidal.

\section{Asthelys careyi Geiger, 2017}

(Figure 1D)

Asthelys careyi Geiger, 2017: 229-230, figs 23-24. Holotype LACM 3320. 5180 m, abyssal plain W of Oregon, S of Gulf of Alaska, Alaska.

Description. Shell $7 \mathrm{~mm}$ (holotype), white, with five smooth, slightly inflated whorls, suture weakly impressed, base convex, smooth; basal angulation slightly projecting, with small channel above; anomphalous; columella narrow.

Distribution. Abyssal plain off Oregon. $5180 \mathrm{~m}$. Known only from holotype. 
Oligomeria Galkin \& Golikov, 1985

(Figure 1E-F)

Oligomeria Galkin \& Golikov, 1985: 22. Type species (OD): O. conoidea Galkin \& Golikov, 1985. Kurile Islands, Russia.

Description. Shell trochiform biconical, predominant spiral sculpture, umbilicate. Monotypic genus.

Oligomeria conoidea Galkin \& Golikov, 1985

(Figure 1E-F)

Oligomeria conoidea Galkin \& Golikov, 1985: 23, figs 1-3. Holotype ZIN 38605. Cape Kitov, Urip, Kurile Islands, Russia, $150 \mathrm{~m}$.

Description. Shell to $4.7 \mathrm{~mm}$, trochiform biconical; spiral cords or carinated cords, $\sim 6$ stronger ones on shoulder, $\sim 15$ weaker ones on base; faint axial sculpture predominantly on early whorls, umbilicus open, no periumbilical cord, no funiculus; columellar wall somewhat thickened, aperture subquadratic.

Distribution. Kurile Islands, Russia, to Aleutian Islands, Alaska $\left(179^{\circ} \mathrm{W}\right) .88-220 \mathrm{~m}$.

Remarks. The strength of the spiral sculpture varies, but is not sufficient to warrant taxonomic recognition, particularly giving the limited material available.

\section{Seguenzia Jeffreys, 1876}

(Figure 2)

Seguenzia Jeffreys, 1876: 200. Type species (M): S. formosa Jeffreys, 1876. Northwest Atlantic.

Description. Shell to $10 \mathrm{~mm}$, thin, fragile, umbilicate or anomphalous, external and internal surfaces with nacreous luster. Apertural lip bordering three labral sinuses often flaring in mature shells. Columella curved, ending abruptly. Sculpture of narrow spiral carinae, basal cords; fine spiral threads, sharp axial riblets curving parallel to labral sinuses.

Remarks. Species occur throughout the world on the lower continental slope and abyssal plain. Seguenzia occidentalis Dall, 1908 (see Keen 1971) is known from the Panamic Province. There are two groups of Seguenzia, 1) specimens with globular shells and with less prominent spiral keels: S. cervola, $S$. macleani, and 2) biconical shells with more prominent spiral keels: S. giovia, S. stephanica.

\section{Seguenzia cervola Dall, 1919}

(Figure 2A-B)

Seguenzia cervola Dall, 1919: 344. Holotype USNM 209229. Off North Coronado Island, Baja California, 618-692 fms [= $1130-1265 \mathrm{~m}]$.

Seguenzia megaloconcha Rokop, 1972: 15, fig. 1. Holotype USNM 701260. SW of Farallon Islands, W of Pioneer Seamount, 3592-3798 m. New synonym.

Description. Shell to $10 \mathrm{~mm}$, globular inflated, suture little impressed; spiral cords decreasing in strength from shoulder to base, one below suture, one on mid-shoulder, more than one dozen from periphery to base; crossed by finest axial lines; umbilicus open, bordered by more or less distinct periumbilical cord, partially covered by umbilical chink, funiculus present; columellar wall thickened, abruptly ending.

Distribution. Oregon $\left(46^{\circ} \mathrm{N}\right)$ to Coronado Islands, Baja Califonia $\left(32^{\circ} \mathrm{N}\right) .1100-3800 \mathrm{~m}$.

Remarks. Seguenzia megaloconcha is a small specimen of $S$. cervola as shown by the identical sculpture on the earlier portion of the teleoconch and the shared umbilical characters.

\section{Seguenzia macleani Geiger, 2017}

(Figure 2C-D)

Seguenzia macleani Geiger, 2017: 231, figs 25-28. Holotype LACM 3321, 5100 m, Aleutian Trench, Alaska. 
Description. Shell to $9.6 \mathrm{~mm}$, globular inflated, suture little impressed; spiral cords decreasing in strength from shoulder to base, one on shoulder, one at suture, a good dozen on base; crossed by fine axial lines; umbilicus wide, no funiculus; columella not thickened.

Distribution. Western Aleutian Islands, Alaska $\left(175^{\circ} \mathrm{W}\right)$ to off Oregon $\left(45^{\circ} \mathrm{N}\right)$. Abyssal plain, $5100 \mathrm{~m}$.

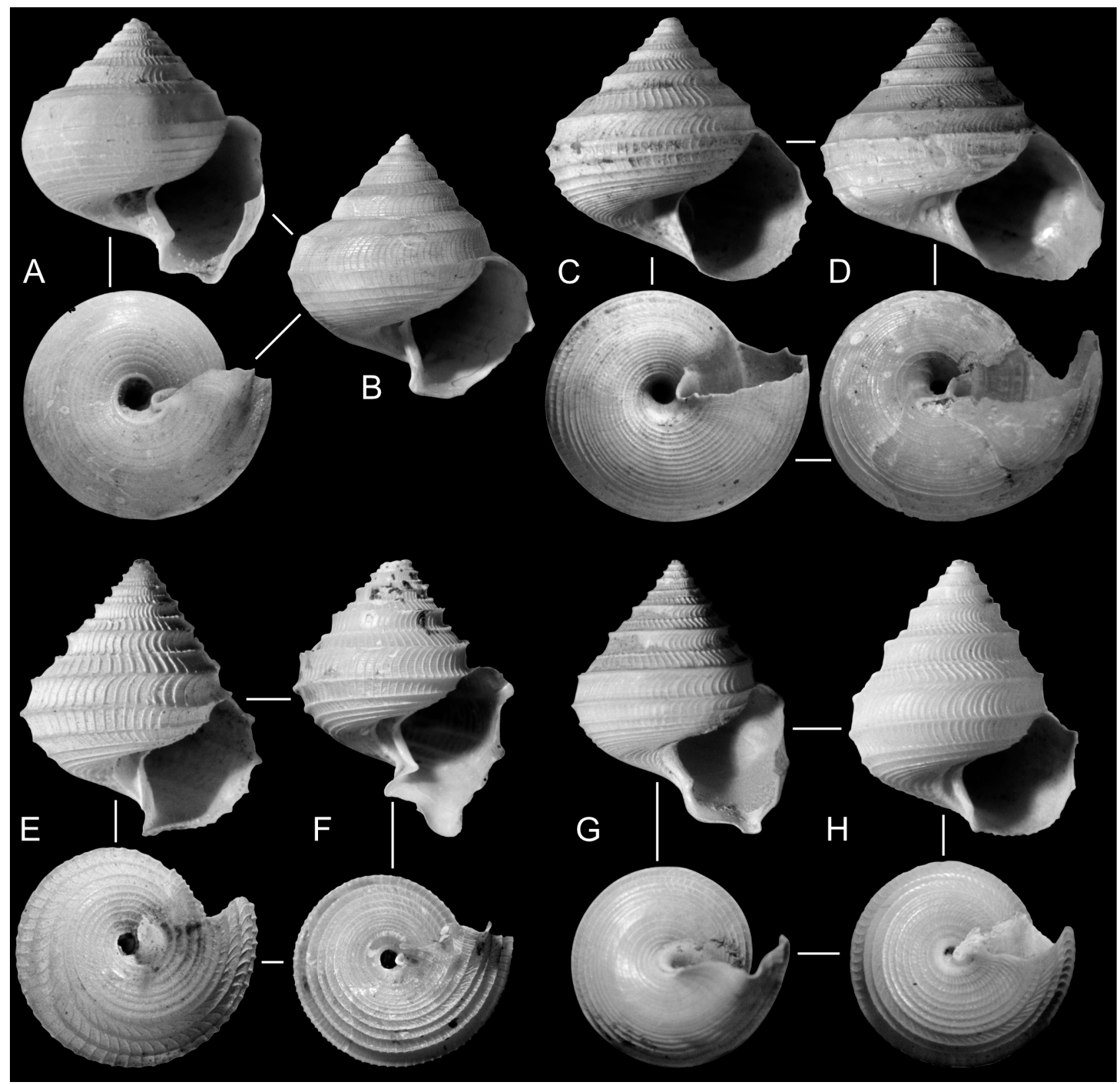

FIGURE 2. A-B. Seguenzia cervola Dall, 1919. A. 1130-1266 m, off North Coronado Island, Baja California (USNM 209229, holotype), 4.5 mm. B. 3592-3798 m, SW of Farallon Islands and W of Pioneer Seamount, off San Francisco County, California (USNM 701260, holotype of $S$. megaloconcha), $9.2 \mathrm{~mm}$. C-D. Seguenzia macleani Geiger, 2017. C. 5100 m, Aleutian Trench at $175^{\circ} 44^{\prime}$ E (LACM 3321), holotype, $8.7 \mathrm{~mm}$. D. $5180 \mathrm{~m}$, abyssal plain W of Oregon, S of Gulf of Alaska (approximately $45^{\circ} \mathrm{N}, 153.8^{\circ} \mathrm{W}$ ) (LACM 3486, paratype), $9.6 \mathrm{~mm}$. E-F. Seguenzia giovia Dall, 1919. E. $874-1097 \mathrm{~m}$, off Santa Catalina Island, Los Angeles County, California (USNM 209228, holotype), 6 mm. F. 3900 m, Tufts Abyssal Plain, W of Lincoln County, Oregon (LACM 2065, holotype of S. quinni), 7.6 mm. G-H. Seguenzia stephanica Dall, 1908. G. 2816 m, Cascadia Abyssal Plain, off Oregon (LACM 70-140.5), 7.1 mm. H. 5100 m, Aleutian Trench, Alaska at $44^{\circ} \mathrm{N}, 175^{\circ} \mathrm{E}(\mathrm{LACM})$, $5.2 \mathrm{~mm}$. 


\section{Seguenzia giovia Dall, 1919}

(Figure 2E-F)

Seguenzia giovia Dall, 1919: 343-344. Holotype USNM 209228. Off Santa Catalina Island, California Channel Islands, 190$216 \mathrm{~m}$ [see remarks below].

Seguenzia quinni McLean, 1985: 337, fig. 2. Holotype LACM 2065. Tufts Abyssal Plain, W of Lincoln County, Oregon, 3900 m. New synonym.

Description. Shell to $7.5 \mathrm{~mm}$, globular biconical; carinated spiral cords below suture, strongest on mid shoulder, from periphery to base approximately 10 of decreasing strength; fine spiral lines between cords; axial cordlets distinct; Umbilicus moderately wide, bordered by spiral carina, with funiculus; Columellar wall thickened, terminating as sharp spur. Flaring of lip variable depending on size, preservation of specimen.

Distribution. Off Oregon $\left(45^{\circ} \mathrm{N}\right)$ to Southern California $\left(33^{\circ} \mathrm{N}\right) .800-3900 \mathrm{~m}$.

Remarks. Seguenzia quinni is a larger, better-preserved specimen of $S$. giovia; note the identical teleoconch sculpture and umbilical details. The type locality of $S$. giovia (Albatross 4408) is most likely erroneous because it is too shallow for seguenziids, and may be any of the Albatross 4400-4407 stations at depths of 450-650 fathoms (820-1190 m), all off Santa Catalina Island, Los Angeles County, California.

\section{Seguenzia stephanica Dall, 1908}

(Figure 2G-H)

Seguenzia stephanica Dall, 1908: 325. Holotype USNM 123034. Ventana Bay, Baja California, $1820 \mathrm{~m}$. Seguenzia caliana Dall, 1919: 344. Holotype USNM 207674. Off San Diego, California, 417 fms [= 762 m]. New synonym. Seguenzia certoma Dall, 1919: 343. Holotype USNM 211167. Off Point Loma, San Diego, California, 565-680 fms [= 1033$1243 \mathrm{~m}]$. New synonym.

Description. Shell to $8 \mathrm{~mm}$, globular biconical; carinated spiral cords below suture, strongest one mid shoulder, approximately $8-15$ from periphery to umbilicus, count increasing with size; intercalated spiral lines at best faint; axial cordlets distinct. Umbilicus very narrow in small specimens, closed by callus in larger shells. Columellar wall thickened, terminating in sharp spur. Flaring of lip variable depending on size, preservation of specimen.

Distribution. Aleutian Islands, Alaska $\left(175^{\circ} \mathrm{E}\right)$ to Peru $\left(3^{\circ} \mathrm{S}\right) .750-5100 \mathrm{~m}$.

Remarks. Smaller specimens have proportionally more pronounced spiral and axial sculpture. The types of the three nominate taxa represent growth stages of the same species.

\section{Adeuomphalus Seguenza, 1876}

(Figure 3)

Adeuomphalus Seguenza, 1876: 10. Type species (M): A. ammoniformis Sequenza, 1876. Plio-Pleistocene deep-water fossil, southern Italy. [see Kano et al. (2009) for potential synonymy of Transomalogyra Palazzi \& Gaglini, 1979 and unresolved erroneous identification of type species.]

Description. Shell to $3 \mathrm{~mm}$, planispiral, teleoconch with axial cords, aperture D-shaped, with thin edge.

Remarks. The placement of the genus is not fully resolved and is included here under Seguenziidae for convenience; see Kano et al. (2009) for details. Of six species, one is known in the northeast Pacific.

Adeuomphalus trochanter Warén \& Bouchet, 2001

(Figure 3)

Adeuomphalus trochanter Warén \& Bouchet, 2001: 132, figs 8f, 151, 16d. Holotype MNHN 21051. Juan de Fuca Ridge, off Oregon $\left(46^{\circ} \mathrm{N}, 130^{\circ} \mathrm{W}\right), 2068 \mathrm{~m}$.

Description. As for genus.

Distribution. Juan de Fuca Ridge ( $\left.46^{\circ} \mathrm{N}\right)$. Hydrothermal vents, $2000 \mathrm{~m}$. 


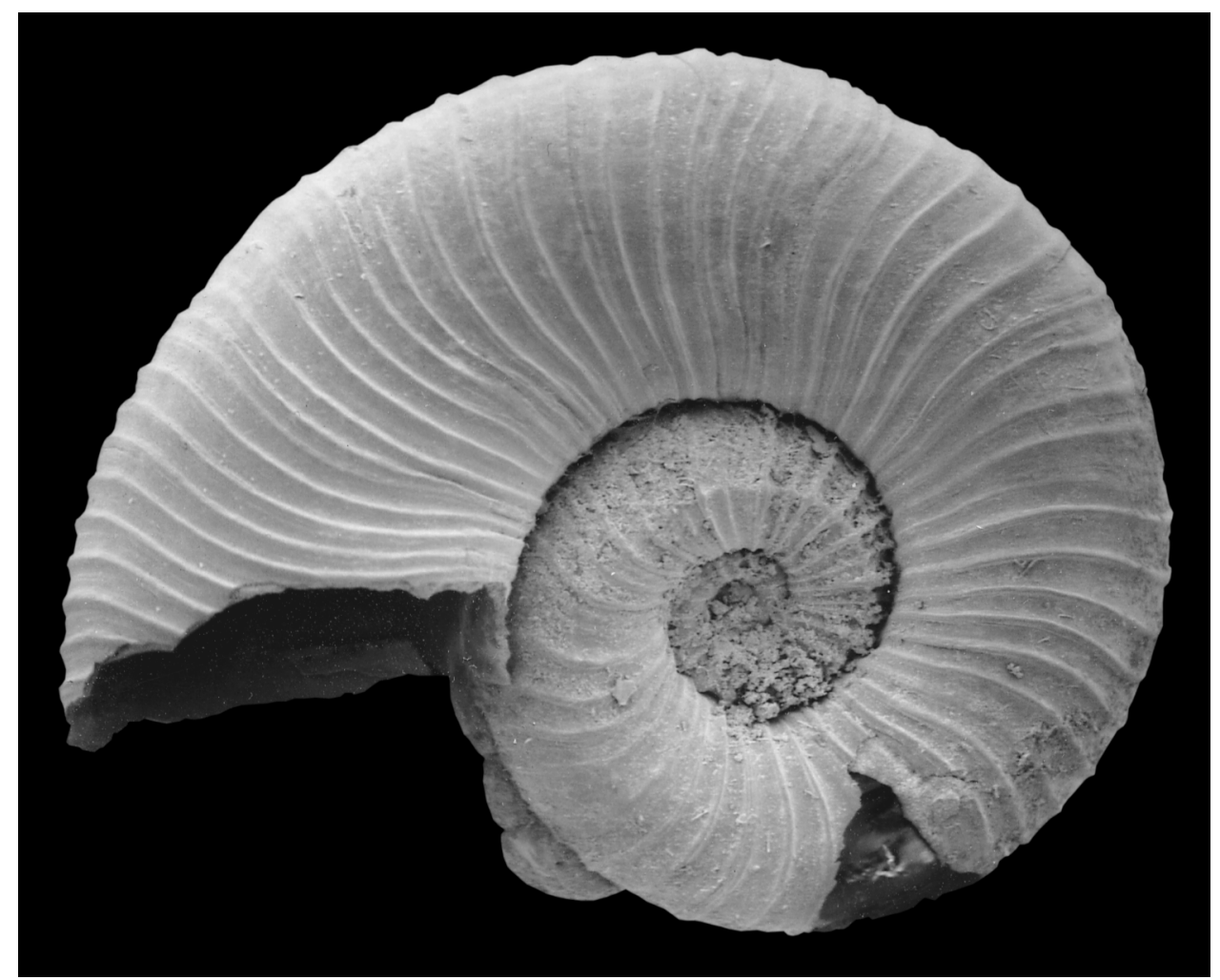

FIGURE 3. Adeuomphalus trochanter Warén \& Bouchet, 2001. 2068 m, Juan de Fuca Ridge, off Oregon (MNHN 21051, holotype), $2.7 \mathrm{~mm}$ [SEM by Anders Warén].

\section{Discussion}

The systematics of seguenziids is mainly plagued by the lack of material. Accordingly, it is difficult to assess intraspecific variability and to determine species boundaries. I follow here the spirit of Dutch botanist's van Steenis, who has been quoted "It is not our task to find out how many species there are, but how few." (P. Hovenkamp pers. comm.), which could also be expressed as the "lumper" approach. The statistical approach to species delimitation, explained elsewhere (Geiger 2012: 25), also comes to bear. For example, if a small number of specimens is significantly different, the differences must be large. In the case of the Seguenzia, the presence/absence of an umbilicus seems to segregate two groups. A second but less clear-cut character is the strong apertural projections, which may, however, break off. The placement and relative strength of spiral cords and ridges can be used as an additional character, while their absolute strength is not indicative of any systematic differentiation. That last set of attributes has been the main source of synonyms, including additional proposed taxa in the McLean manuscript. It is not known, but also unlikely, that those McLean manuscript names were applied by him to specimens in other collections. All those manuscript names have been evaluated and found to be unwarranted, except those published in Geiger (2017).

The generic assignment of Carenzia inermis is uncertain. It occupies a position intermediate between $C$. golikovi with a subquadratic outline of whorls, and Asthelys with a more triangular outline of whorls and a rather distinct peripheral keel. Carenzia inermis is kept in Carenzia because of Quinn's assignment to this genus, who also described Asthelys. It is entirely unclear whether/which shell characters are meaningful in the systematics of seguenziids, or which morphological characters are indicative of generic boundaries.

On-line taxonomic data portals. In the current landscape of on-line taxonomic databases one cannot escape noting the proliferation of partially to heavily overlapping portals (e.g. Encyclopedia of Life, EuNomen, FishBase, fossilworks, ITIS, Kew Checklist of Selected Plant Families, MolluscaBase, Paleobiology Database, Species2000, Tree of Life, Wikipedia, WoRMS, ZipCodeZoo), to name but some of the most prominent examples. The overlap of the WoRMS and MolluscaBase databases is particularly striking. Given the checkboxes in the WoRMS taxon query for "extant" and "marine taxa", that when un-checked also include 
fossils as well as freshwater and terrestrial taxa, it appears that MolluscaBase is an exact subset of WoRMS. Perhaps WoRMS could become WoRAS (World Register of All Species)? That abbreviation would be quite fitting as it is related to the computing term WORA (Write Once Run Anywhere). It would also reduce the number of competing portals and unify diverse taxonomic inventory efforts. As a malacologist, I would welcome for MolluscaBase to disappear, as all its entries are already included in WoRMS. Such a step in the right direction would send the appropriate and refreshing signal, as when CLEMAN became the broader WoRMS. Fusion and consolidation is highly desirable, if not required, to accelerate progress towards a truly comprehensive taxonomic inventory.

A problem with multiple data portals is that none of them are complete, and that specialists will not look over dozens of portals and contact all their administrators to root out problems. For instance the fossil abalone Haliotis lomaensis Anderson, 1902 is not found in either MolluscaBase or WoRMS, but is readily appearing in fossilworks. The species is far from obscure, as it has frequently been cited as one of the oldest abalone fossil (reviewed in Geiger \& Groves 1999). The omission in MolluscaBase/WoRMS is not because no fossil abalone have been included. In fact, it contains obscure taxa such as the fossil Haliotis matihetihensis (Eagle, 1999). A single, combined taxonomic portal would not have such problems.

A comparison to other disciplines is highly illuminating. While nobody would dream of having COI/ BOLD data separate from GenBank, this kind of provincial mentality is pervasive in the taxonomic community. The balkanization exists both along the geographic as well as along the taxonomic axes. The amount of duplication, superfluous work, and funding that is expended (or dare I say wasted?) on all those parallel efforts is staggering. Imagine how much further along we could be with a single portal. In the case of taxonomic data portals, too many cooks most definitely spoil the broth. We need a single, GenBank-like portal for all biota of the entire globe. One cannot help but to admire the genetics community for maintaining a single, well-organized, and working repository, which is universally accepted as the one and only repository for such data. Once there is a single taxonomic portal, then it also becomes more attractive for specialists to contribute to that single resource.

\section{Acknowledgements}

The photographs shown here were all taken by the late James H. McLean. One anonymous reviewer helped to improve the manuscript. Lindsey Groves and Jann Vendetti discharged editorial duties.

\section{References}

Bouchet, P. (2018) Seguenziidae. In: MolluscaBase (2018). Accessed through: World Register of Marine Species at http:// www.marinespecies.org/aphia.php? $\mathrm{p}=$ taxdetails\&id $=23116$ on $2018-12-23$

Dall, W.H. (1908) Reports on the dredging operations off the west coast of Central America to the Galapagos, to the west coast of Mexico, and in the Gulf of California ... XIV. The Mollusca and Brachiopoda. Bulletin of the Museum of Comparative Zoology, Harvard, 43, 205-487, pls. 1-22.

Dall, W.H. (1919) Description of new species of Mollusca from the North Pacific Ocean in the collection of the United States National Museum. Proceedings of the United States National Museum, 56(2295), 293-371. https://doi.org/10.5479/si.00963801.56-2295.293

Galkin, Yu.I. \& Golikov, A.N. (1985) New genus and species of gastropods of the family Trochidae from the northwestern pacific. USSR, Academy of Sciences, Proceedings of the Zoological Institute, Leningrad, 135, 22-25.

Geiger, D.L. (2012) Monograph of the Little Slit Shells. Santa Barbara Museum of Natural History, Santa Barbara. 1291 pp.

Geiger, D.L. (2017) Four new Vetigastropoda (Anatomidae, Seguenziidae) from the northeastern Pacific. The Nautilus, 131, 226-232.

Geiger, D.L. \& Groves, L.T. (1999) Review of fossil abalone (Gastropoda: Vetigastropoda: Haliotidae) with comparison to Recent species. Journal of Paleontology, 73, 872-885. https://doi.org/10.1017/S0022336000040713

Jeffreys, J.G. (1876) Preliminary report of the biological results of a cruise in H.M.S. Valorous to Davis Strait in 1875. Proceedings of the Royal Society, London, 25, 177-230.

Kano, Y. (2008) Vetigastropod phylogeny and a new concept of Seguenzioidea: independent evolution of copulatory organs in the deep-sea habitats. Zoologica Scripta, 37, 1-21. 
https://doi.org/10.1111/j.1463-6409.2007.00316.x

Kano, K., Chikyu, E. \& Warén, A. (2009) Morphological, ecological and molecular characterization of the enigmatic panispiral snail genus Adeuomphalus (Vetigastropoda: Seguenzoidea). Journal of Molluscan Studies, 75, 397-418.

https://doi.org/10.1093/mollus/eyp037

Keen, A.M. (1971) Seashells of Tropical West America, second edition. Stanfort University Press, Stanford.

McLean, J.H. (1985) Two new northeastern Pacific gastropods of the families Lepetidae and Seguenziidae. The Veliger, 27, 336-338.

Marshall, B.A. (1983) Recent and Tertiary Seguenziidae (Mollusca: Gastropoda) from the New Zealand Region. New Zealand Journal of Zoology, 10, 235-262. https://doi.org/10.1080/03014223.1983.10423911

Marshall, B.A. (1991) Seguenziide from New Caldedonia and the Loyalty Islands. Résultats de Campagnes MUSORSTOM 7. Mémoires du Muséum national d'Histoire naturelle (A), 150, 41-109.

Poppe, G.T., Tagaro, S.P. \& Dekker, H. (2006) The Seguenziidae, Chilodontidae, Trochidae, Calliostomatidae and Solariellidae of the Philippine Islands. Visaya, Supplement 2, 1-228.

Quinn, J.F., Jr. (1983a) Carenzia, a new genus of Seguenziacea (Gastropoda: Prosobranchia) with the description of a new species. Proceedings of the Biological Society of Washington, 96, 355-364.

Quinn, J.F., Jr. (1983b) A revision of the Seguenziacea Verrill, 1884 (Gastropoda: Prosobranchia). I. Summary and evaluation of the superfamily. Proceedings of the Biological Society of Washington, 96, 725-757.

Quinn, J.F., Jr. (1987) A revision of the Seguenziacea Verrill, 1884 (Gastropoda: Prosobranchia). II. The new genera Hadroconus, Rotellenzia, and Asthelys. The Nautilus, 101, 59-68. https://doi.org/10.5962/bhl.part.17407

Quinn, J.F. (1991) Systematic position of Basilissopsis and Guttula, and a discussion of the phylogeny of the Seguenzoidea (Gastropoda: Prosobranchia). Bulletin of Marine Sciences, 49, 575-598.

Rokop, F.J. (1972) Notes on abyssal gastropods of the eastern Pacific, with descriptions of three new species. The Veliger, 15, $15-19,2$ pls.

Salvini-Plawen, L.v. \& Haszprunar, G. (1987) The Vetigastropoda and the systematics of streptoneurous Gastropoda (Mollusca). Journal of Zoology, London, 211, 747-770. https://doi.org/10.1111/j.1469-7998.1987.tb04485.x

Seguenza, G. (1876) Studii stratigrafici sulla formazione pliocenica dell'Italia Meridionale. Bollettino del real Comitato Geologico d'Italia, 7, 7-15.

Warén, A. \& Bouchet, P. (2001) Gastropoda and Monoplacophora from hydrothermal vents and seeps, new taxa and records. The Veliger, 44, 116-231. 